\title{
Rafe's Rebellion: Reconsidering The Knight of the Burning Pestle
}

ROBERT ZACHARIAS

University of Guelph

En reconsidérant le contexte politique et théâtral de la pièce The Knight of the Burning Pestle (1607) de Francis Beaumont, cet article propose que Rafe, l'apprenti citoyen qui prend le rôle éponyme du chevalier gaffeur, est un personnage beaucoup plus significatif que perçu habituellement. Écrit et joué immédiatement après la révolte des Midlands, le portrait que fait la pièce du jeune apprenti, qui, devenu Lord May, réuni une petite armée d'apprentis avant qu'il ne soit soudainement tué, semble conçu pour exprimer les anxiétés de l'époque à l'égard des classes inférieures, de la nature des représentations théâtrales et de l'agitation sociale, et ce à travers plusieurs éléments méta-théâtraux. L'auteur propose que cette comédie ne doit pas nous détourner de ses implications sérieuses, et que le rôle de Rafe dans la peau d'un chevalier a probablement été plus effrayant que comique.

"Show to the world that you can as well brandish a sword as shake an apron." (Rafe $\left.{ }^{1}\right)$

I $\mathrm{n}$ the spring of 1607, May Day festivities in the English Midlands spiralled out of control and into riots that would become the last large peasant revolt in English history. ${ }^{2}$ Although the enclosure of public lands had sparked smaller and localized riots with some regularity over the preceding decades, the "Midlands Revolt" was unique both in scale and form: in a mixture of festival and violence, thousands of protestors roamed the countryside, levelling enclosure fences and celebrating with music and dance. The gentry turned to their peasant militias to restore order, only to find that their peasants were the very ones rioting. As the revolt spread from township to township, citizens of neighbouring towns used Shrove Tuesday and Trinity Sunday celebrations to escape newly imposed curfews and join in the protests. Two months after the riot's carnivalesque beginnings and with no end in sight, King James intervened violently to suppress the revolt: some 50 peasants were killed in the ensuing confrontations, and the rebellion's leaders were drawn, quartered, and placed on display. That same year, a young playwright by the name of Francis Beaumont rushed out a play mocking aristocratic pretensions that concludes with a grocer's apprentice using his power as Lord of the May Day revels to 
raise an armed militia, gathering his motley crew at the strategic Mile End - both a training ground for the citizen militias and a key meeting site in the infamous Peasant's Revolt of 1381 - and calling on them to "show to the world [they] can as well brandish a sword as shake an apron" (v.157-158). ${ }^{3}$ The play was presented as a comedy, but no one laughed. In its opening performance at London's Blackfriars Theatre, Beaumont's The Knight of the Burning Pestle was an utter failure.

Four centuries after its initial performance, The Knight is enjoying a rebirth of sorts, with critics marvelling at the play's originality, its formal complexity, and the sophistication of its meta-theatrical elements. Coming a long way from its status as a rare flop in Beaumont's otherwise wildly successful career as a playwright, today The Knight is the "only play in the Beaumont and Fletcher canon that is widely admired." Along with its recent praise has come wide-ranging speculation as to the reasons for its early failure, with some critics arguing that the play's social satire was too abrasive for its largely upper-class audience, and others countering that its satire was not biting enough, with still others suggesting it was too sophisticated and complex for its audience to understand. 5 I want to add another possibility: comedies often address the anxieties of their age, of course, but given the play's clear allusions to the very real threat of lower-class riots and uprisings, its engagement with contemporary concerns surrounding theatrical mimesis and carnival days, and the abrupt transformation of the play's central character in its final scenes, it seems possible that Beaumont's audience found his representation of Rafe, a youth who uses a carnival day to raise a militia of disgruntled apprentices, more frightening than funny.

\section{The Death (and life) of the Author}

In her literary-biographical study entitled Francis Beaumont, Lee Bliss writes that “perhaps anyone's first, surprised and delighted, reading of The Knight sparks curiosity about its author." 6 One glance at the criticism of the play is enough to confirm the claim: William Appleton notes what he calls "the predominantly bibliographical nature of many studies of Beaumont and Fletcher,"7 and critics like Philip Finklepearl and Sandra Clark have shown just how consistently Beaumont's "aristocratic" heritage has coloured the critical reception of his work. ${ }^{8}$ Uncertain as they are, the biographical details of Beaumont's life-his status as a member of the aristocracy, his grandfather's position as a well-paid judge, and so on-have routinely been offered as primary evidence for critical interpretations that read his plays as politically innocuous, socially trite, or simple fodder for the crown. It was Samuel Taylor 
Coleridge who offered the earliest and most influential of such critiques when he casually dismissed both Beaumont and Fletcher as "servile jure divino Royalists."9 Coleridge's assessment has proved difficult to shake: in a chapter unequivocally entitled "Beaumont and Fletcher: Jacobean Absolutists," for example, John F. Danby names them "James's unconscious agents" ${ }^{\circ}$; Margot Heinemann calls them "royal slaves"11; and Dana Aspinall cites "Beaumont and Fletcher's compelling reputations as royalist playwrights" to set up her argument that in The Knight, Beaumont "desperately [wants] to elide" the "folk humor of the lower class."12 The implicit (and, at times, explicit) assumption has been that Beaumont's plays must support the status quo of the seventeenth-century social hierarchy, because the status quo supported him.

More recently, however, critics have begun to question the extent to which Beaumont's upbringing would have predisposed him to favour the court, and to challenge the implications the assumption has held for his work. For example, while it is true that Beaumont's grandfather was at one point an influential judge, he was later convicted, and heavily punished, for cheating the government out of large sums of money. Finklepearl recommends that "in assessing the attitude toward princes and courts in Beaumont's plays, it is useful to recall that during the entire period in which he was a writer, most of the income from his family's estate was being siphoned off by the Crown" due to an obscure law against Catholic recusants. ${ }^{13}$ It may be also useful to recall that many of Beaumont's close relatives were well known to be closet Catholics, several of whom were implicated in the 1605 Gunpowder Plot; others were prominent liberal MPs and "among the king's most vocal opponents in Parliament." ${ }^{4}$ All of this is enough to lead Finklepearl to the conclusion that "the playwrights' aims were almost precisely the opposite of those usually assigned to them."15

A common corollary to critiques that emphasize Beaumont's aristocratic lineage has been the Jacobean court's close association with the theatre. However, the company for whom The Knight was originally written, the Blackfriars, had at best a troubled relationship to James's reign. Although James initially issued a patent allowing the company to call itself the Children of the Queen's Revels, the crown had severed its connection with the group by 1606, after the company "gave offence by the satiric strain in its plays." ${ }^{16}$ Far from catering to the crown, The Knight's original players had been repeatedly punished by James for their presentation of "politically inflammatory allusions"17 — to the point where the performance of a play just prior to Beaumont's own had ended in several arrests. As Leggatt reminds us, then, it is 
worth noting that The Knight was written for a company that had just had its royal patronage withdrawn. ${ }^{18}$

Still, Bliss's warning that Beaumont's biographical details, no matter how suggestive they may be, "should not generate hasty assumptions," 19 is well placed. Moreover, the on-going focus on Beaumont's biography in critiques of The Knight is somewhat surprising, coming 40 years after critics began discussing the death of the author. I have traced these debates at some length not to simply turn the tables on those who have used Beaumont's biography to read him as "deferential, glad to be of use' to the king and court," ${ }^{\circ}$ but rather to note that even within the context of the biographical criticism that has often dominated the play's criticism, space has been cleared for a re-consideration of The Knight. Though it is hardly prudent to extrapolate too much from an author's family tree, and poor practice to assume a play's politics are determined by the reputation of the company that plays it, there is ample evidence to overturn the standard portrait of Beaumont and his work as unproblematic supporters of the status quo.

\section{Before The Knight: Rafe as Amateur Actor}

The Knight of the Burning Pestle begins with a prologue offering an induction to The London Merchant, a play-within-the-play that the players ostensibly mean to perform. The Prologue delivers no more than three lines of his opening monologue when he is interrupted by a citizen in the audience who, having taken offence at the play's title, demands the performance of a new play "in honour of the commons of the city," that would show a "grocer do rare things" (Ind.25-26; 56). And so it is that Rafe, the citizen's apprentice, makes his way to the stage for the first time. Colin Counsell's dismissal of Rafe is typical of how his character has been received in much of the play's criticism: "the adventures of Rafe are not to be taken seriously," Counsell writes, as "his own story is clearly a mock romance." ${ }^{21}$ When we consider his character as an upstart grocer apart from his role as the knight, however, or when we separate the rhetoric of his masters from his own lines, it should become clear that to bypass Rafe as merely "the personal champion of George and Nell”22 is a mistake.

Although Rafe spends most of the play acting the part of a ridiculous knight errant, his most compelling moments come before and after he takes on the eponymous role, and our reading of these passages should not be completely determined by the character he portrays during the rest of the play. For example, the very first lines he speaks directly connect him to early modern London's anxieties about social mobility and political upheaval. After being described by Nell as a terrifying man 
who scares both his masters and their children (Ind. 68-72), Rafe enters the play when Nell prompts him to "show the gentlemen what thou canst do; speak a huffing part” (Ind. 73-74). Surprisingly, the lowly grocer's helper responds by climbing onstage and delivering some of Shakespeare's most famous lines, reciting Hotspur's challenge to inherited notions of nobility (see below). Just as surprisingly, Rafe's recitation of Hotspur's lines has usually been taken as proof that Rafe is a bumbling fool like his masters: Stanley Wells's article on "Shakespearian Burlesques” opens with what he calls Rafe's "misquotation"23; Doebler claims the lines are "quoted, with the alterations of a weak memory, from Hotspur's speech" ${ }^{24}$; and Bliss takes the passage as "a debasement both of the heroic ideals and the dramatic forms associated with them."25 On closer inspection, however, there seems little reason to take Hotspur's lines in The Knight as a mockery. If the fact that Rafe's delivery of the lines impresses George and Nell tells us little, it is still worth noting that his performance seems to have been of sufficient quality to convince the Prologue he can act, earning him a suit of apparel and a spot on stage (Ind. 87). Moreover, the citation shows that Rafe is familiar with the theatre, much like George and Nell's earlier recitation of contemporary titles (Ind. 19-22; 51-53). The titles referred to by the citizen and his wife are "plays celebrating citizen achievement and catering to citizens tastes" 26 and clearly reflect their social aspirations; if we apply the same standards to Rafe's citation of Hotspur's lines, we find ourselves with a surprisingly ambitious grocer's apprentice. Most importantly, however, there seems to be little basis to the claim that Rafe's recitation of Shakespeare's lines are mocked through "the alterations of a weak memory," 27 as Rafe's lines, shown in the left column below, are all but identical to Hotspur's own:

\author{
By heaven, methinks it were an easy leap \\ To pluck bright honor from \\ the pale-fac'd moon, \\ Or dive into the bottom of the sea, \\ Where never fathom line \\ touch'd any ground, \\ And pluck up drowned honor \\ from the lake of hell.
}

The Knight (Ind. 77-81)

\author{
By heaven, methinks, it were an easy leap, \\ To pluck bright honour from \\ the pale-fac' $d$ moon \\ Or dive into the bottom of the deep, \\ Where fathom-line could \\ never touch the ground, \\ And pluck up drowned honour by the locks. \\ I Henry IV $(1.3 .199-203)^{28}$
}

Even granting that Rafe's "from the lake of hell" is somewhat more melodramatic than Hotspur's own "by the locks," the passages are otherwise nearly identical. Given their similiarity, I suspect critics have been reading Rafe's later role as a knight errant 
back onto this opening scene, and thus obscuring the fact that his initial lines connect the grocer's apprentice with one of Shakespeare's most well-known rebels.

Since it is hardly self-evident that Rafe's alteration of Hotspur's lines is meant as burlesque, it is worth looking closer at the implications of this pairing. Shakespeare's I Henry IV chronicles the 1403 rebellion led by Harry (Hotspur) Percy, whose attempt to dethrone King Henry very nearly succeeds before Hotspur is killed in battle. According to Stephen Greenblatt, Shakespeare portrays Hotspur as "an impassioned embodiment of medieval chivalry, eager above all for honor and for the glory to be won in battle."29 Beaumont's decision to connect Rafe to this wellknown representative of political upheaval and "embodiment" of chivalry stands in stark contrast to Rafe's later portrayal of a bumbling knight used by Beaumont to satirize both the idea of chivalry and the possibility of meaningful rebellion. Depending on how the lines were delivered, then, this initial image of Rafe as a London apprentice with a bad temper and dangerously high political aspirations may not have been particularly funny - and it is not likely that The Knight's audience would have missed Beaumont's allusion to Hotspur, for I Henry IV was the most popular of Shakespeare's plays at the time, and, as is often noted, the audience at the private Blackfriars theatre would have been relatively sophisticated. If his connection to rebellion and upheaval seems to fade away while Rafe plays the part of the knight, this early comparison of Rafe to Hotspur will come back to haunt the play's concluding scenes, lending some vigour to Rafe's role as militia leader who, once again, is fighting for honour.

Beaumont's play is littered with intertextual references, however, and few of them offer Rafe as threatening or as flattering a comparison as the first. In fact, the very next time Rafe appears — in his first scene as the knight - he is reading aloud from a hybridized copy of Palmerin of England (1596). Munday's text was a "vastly popular Iberian romance" of love and chivalry written in an "absurdly mannered genre," 30 setting up an easy reading that would equate Rafe with the bombastic and over-the-top characters of Munday's romance. However, Beaumont is careful to draw a distinction between Rafe and Munday's characters, having Rafe carry the book on stage and read aloud from it (rather than having him recite the lines as his own, as he did with Hotspur's lines), and having him exaggerate his distance from the text by commenting upon the passage before very consciously beginning to act a similar part. After reading from the text, Rafe wonders aloud why the kings do not "destroy these giants" who "do much hurt to wandering damsels that go in quest of their knights" (I. 229-244), before deciding to play the role of the knight. Depending on how we are reading Rafe, his inversion of romantic conventions- 
wandering damsels on quests for their knights — can be taken to demonstrate either his stupidity or his wit. Is he actually confusing the conventions of chivalry, or is he mocking them? The fact that the citizen and his wife miss the joke is beside the point; it certainly does not mean that Rafe was not mocking the romance. That Rafe's next lines offer a fairly pointed critique of the many newly-minted knights roaming London at the time-James had resorted to selling knighthoods for forty pounds apiece — suggests to me that Rafe, as an aspiring actor, is offering a series of comedic critiques before taking on the role of the knight, mocking both the purchase of knighthoods and the overblown rhetoric of the romance in order to separate himself from both.

There are other reasons to take Rafe seriously as well. As Bliss reminds us, Rafe is shown to be "an ardent amateur actor (and playgoer?), with at least Mucedorus, I Henry IV, and The Spanish Tragedy in his repertoire." ${ }^{11}$ While George and Nell make the mistake of equating Rafe with the ignorant knight errant, then, it is important that we recognize that Beaumont is portraying an amateur actor who is acting the fool, cow-towing to the "low brow" humour of the theatre audience. Beaumont takes pains to emphasize the moment Rafe takes on the role of the knight, having him ask, "What brave spirit could be content to sit in his shop ... that might pursue feats of arms?" (I. 251-254), and showing him deliberately complete the transition by announcing, "I will be the said knight" (I. 262). The distinction between Rafe as an amateur actor and the various parts he plays in the course of The Knight, then, is carefully drawn, and if we equate Rafe with the parts he plays we make the same mistake as George and Nell, who are roundly mocked for being unable to distinguish between the reality of the actors on the stage and the imaginary world they present.

Recognizing Rafe as an actor may seem obvious, but it is important in its implications, for it puts Rafe in the very highest position of power within the social economy established by the play. In fact, Rafe occupies not only the role of actor, but also the privileged (if difficult) position as both the playwright and director of the citizens' play. Bliss refers to Rafe as a "farcical figure of the dramatist and his plight," who "must create dialogue and motivation that will give life and shape to the rather skimpy situational cues provided by an audience that is, quite literally, both his master and 'customer." ${ }^{2}$ Just as Beaumont emphasized Rafe's status as an actor, he clearly foregrounds Rafe's position as director: Rafe patiently instructs his two apprentices on how properly to burlesque the chivalric romance (I. 259-268; 284-300), and, during his elaborate death speech, he goes to great lengths to try to weave the disparate adventures he was sent on by the citizens into something resembling a narrative arc. ${ }^{33}$ When we realize that actors and playwrights are the only members 
of Jacobean society that the play does not mock-the boorish merchant class of citizens, the uneducated working poor, and the wealthy aristocrats are all heavily satirized, with only the knowing actors winking at the audience throughout-Rafe's positioning as a playwright and actor ought to earn him our respect, and gives us yet another reason to take his late transformation seriously.

\section{Rafe's Rebellion}

After taking on the role of the knight errant, Rafe stays "in character" for three of The Knight's remaining acts, rescuing the customers of a barber he mistakes for a giant, spurning the advances of a princess to stay true to a cobbler's maid named Susan, and the like. After the fourth act, however, Rafe slips out of the role of the knight, a shift in character that is accompanied by a marked shift in both the structure and the tone of the play. 34 "He hath been long enough upon adventures," George decides during the fourth interlude, demanding loudly that Rafe return to London (Int. IV, 16-17). Rafe obligingly switches characters once again, and while the plot of The London Merchant stumbles onward, The Knight of the Burning Pestle has concluded. During the fourth interlude and final act, Rafe alternately takes on roles of May Lord, the leader of a London trainband, and his own ghost. If the rest of the play can seem dizzying at times, this final sequence can feel as if the play has lost its focus altogether. Critics have had a tough time with Rafe's closing vignettes: Sheldon Zitner notes that they have often been seen as "ragged," and writes that for many critics, "Beaumont seems to have run out of invention and ended his play with clever improvisations irrelevant to the earlier materials." 35 Lucy Munro explains their incongruity by suggesting that it is "partly dictated by the characteristics of romance, which tends to be episodic," 36 while Tiffany Stern suggests that because of the "mixed demands on audience attention," Blackfriars dramatists were "constantly seeking ... to surprise and titillate their audience." ${ }^{37}$ It is Lee Bliss, however, who comes closest to identifying what I take to be the true significance of these scenes. After suggesting that the varied performances are further evidence of Rafe's "imaginative range and versatility" as an actor, she notes in passing that "the last three stipulated episodes crown Rafe's efforts, even though they return him to London and his 'real' apprentice status." ${ }^{8} 8$ Though she feels it necessary to couch the reality of Rafe's return within the caution of quotation marks, it is of utmost importance to recognize that in these final scenes Rafe has returned to contemporary London, and is essentially playing a politically ambitious version of himself. 
Divided only by a short (but not unrelated) scene from The London Merchantshowing a young, disinherited apprentice (Jasper) deceive a wealthy merchant (Venturewell) — Rafe's May Lord and Mile End scenes invoke the popular anxieties that surrounded both carnival days and popular uprisings. Rafe's part as May Lord is extremely brief - comprising just one speech totalling 35 lines — but it is significant both for the historical context of the play and for its elevation of Rafe to yet another position of authority. An annual festival day marking the beginning of spring, May Day was accompanied by massive popular celebrations and the overturning of social conventions; as such, it was a time of great concern for the city's elite. As Mikhail Bakhtin points out, "on May Day eve one is permitted to look at the world fearlessly and impiously," and it is for this reason that the day constitutes a challenge to those who benefit from an unquestioned social order. ${ }^{39}$ The challenge was not always strictly symbolic: the festival had a long history of breaking out into very real riots; as noted in the opening of this essay, the Midland Revolt of 1607 had erupted on May Day the very year Beaumont presented his play. ${ }^{40}$ As an outbreak of social unrest, the Midlands Revolt was hardly an isolated event, but even though it took place outside the city, it was certainly the most memorable: "throughout the next decade consciousness of the revolt in 1607 was engraved on the minds of peasants and authorities alike, [and] it was frequently referred to either as an exemplar for further action or as a warning of the potential ramifications of riots." 41 The fact that the most recent May Day celebrations had spiralled out of control into a deadly battle between landowners and peasants gives us reason to think that the wealthy members of the Blackfriars' audience would have felt anxious about any reference to May Day, never mind a presentation of a peasant May Lord who leaps from May Lord to militia leader.

Of course, Rafe is not a peasant per se, if by "peasant" we mean a subsistence farmer, but as a lowly apprentice he was certainly part of the lower class in general, which was often imagined, in contrast to the nobility and aristocracy, as an indistinguishable mass. Moreover, his status as an apprentice not only works to heighten the comic absurdity of his (feigned) delusions of grandeur, it also serves to intensify the threat he poses to those who benefit from an unquestioned social order-for the large number of disenchanted and poorly-paid young men serving as apprentices in London was a serious security concern at the time. For example, the Lord Mayor's letter to the Privy Council in 1597, which resulted in the temporary closure of all of London's theatres, gives the following reason for the closure: "we have found by the examination of diverse apprentices and other servants who have confessed unto us that the said stage plays were the very places of their rendezvous, appointed 
by them to meet with such others as were to join with them in their designs and mutinous attempts." 42 As Roger Manning writes, "the popular disturbances that are so prominent a feature of the late Elizabethan period were usually attributed to 'apprentices', for lack of a better term to describe the amorphous London 'crowd' of these tumultuous decades." In fact, Manning goes on to note that the "archetype of apprentices' riots" was called the "Evil May-Day Insurrection of 1517," a particularly bloody festival night that resulted in having the celebrations "officially discouraged and ceased to be kept in London for a century, resurfacing only in the early-Stuart Period." 43 The recent return of May Day events would, of course, have served only to further the carnival's reputation as politically volatile, and the connection between May Day and the "archetypal" apprentice riots lends further weight to a claim that Rafe's reign as May Lord would have been understood to be pregnant with the potentiality of revolution. ${ }^{44}$

As May Day Lord, Rafe wears symbols that have been "adapted from military usage," 45 his sash and staff reminding us that, historically speaking, there is no great leap between the carnival and the military. Accordingly, we should not be surprised to see Rafe's next role: when Nell calls on her husband's apprentice to "call all the youths together in battle-ray, with drums, and guns, and flags ... and let your flags fly, and cry, 'Kill, kill, kill!'” (v. 57-62), Rafe moves quickly from his position of May Lord to take up the leadership of a militia. In his portrayal of an apprentice who clambers onto a theatre stage and, after stepping out of character, "call[s] all the youths together in battle-ray," Beaumont is, at the very least, playing to the oft-expressed fear that apprentices might gather ranks in local theatres to raise trouble. Rafe's militia is certainly satirized by Beaumont, but his audience would not have been as predisposed as we may be to consider such a motley crew harmless, for, as we have seen, political unrest was a very real anxiety in that age, and rioting apprentices constituted a very real threat to the social order. Indeed, the setting Beaumont chooses for Rafe's muster may contain a nod to another of England's most famous uprisings. While there were numerous other training grounds for the citizen militias that were formidable during Elizabeth's reign but that would fall into disarray during James's tenure, Mile End was the location where the peasants gathered during the infamous Peasants' Revolt of 1381 . During the so-called "Great Revolt," tens of thousands of peasants rebelled against rising taxation, storming through London and even executing noblemen before being granted a meeting with the young King Richard II (who defused the rebellion with a series of generous promises upon which he would later renege). The most famous popular rebellion in English history, the Peasants' Revolt held an important role in the national con- 
sciousness and folk memory of Beaumont's time as "the classic example of the fate that would befall a society where the natural principles of subordination collapsed and chaos displaced order." 46

If Rafe's mustering of his apprentices is clearly comical- he notes with displeasure that they stink of venereal disease, for example - the closing speech he delivers to his motley crew is not. "Gentlemen, countrymen, friends and my fellow-soldiers," he begins. "I have brought you this day, from the shops of security and the counters of content, to measure out in these furious fields honour by the ell, and prowess by the pound ... Bear yourselves in this fair action like men, valiant men, and free men!” (v. 138-144). In raising the question of honour, Rafe is returning (and attempting to fulfill?) his earlier declaration, via Hotspur's lines, that his personal aspiration is to "pluck bright honor from the pale-fac'd moon." Moreover, Rafe leaves the enemy of the militia conspicuously unnamed, simply calling on his men to "fear not the face of the enemy" and to "scour me this famous realm of enemies" (v. 145; 156). Exactly who this crew of apprentices understands to be their enemies is left up to the imagination of the audience, and given the history of apprentices rising up against the city's elite - be they their merchant masters, the nobility, or the aristocracy - it would not have been difficult for the audience to imagine themselves as the object of the militia's anger. Moreover, the ambiguity of the "enemy" in Rafe's rebellion reflects the fact that there does not seem to be any single target for Beaumont's critique, for, as mentioned earlier, the play mocks the working poor, the merchants, and the nobility alike - a point we will return to shortly.

Finally, although Dillon writes that Rafe's position in the play is "undercut" by his portrayal as an active participant in the May Day revels, since it "presents an image in outright contradiction to the preceding picture of Rafe as noble captain of the musters, trained to police exactly the kind of disorder that he now admits to joining in," 47 Beaumont reminds his audience of the fact that the militias were formed by "the peasantry itself - the very class which was likely to have been provoked into revolt." 48 The predictable results had recently been played out in the Midland Revolts, where the village militias refused to take up arms against their neighbours, and even began to take up their cause. ${ }^{49}$ Far from seeming improbable, then, it is the very likelihood of the revellers becoming rioters, emphasized by the fact that the same actors would have been playing the parts of each crowd, which would have made The Knight's final scenes so worrying. Moreover, Dillon has mistakenly placed Rafe's role as captain of the musters ahead of his role as May Day Lord, and it is important that Rafe be seen to move from knight errant to May Lord to militia 
leader, for the sequence highlights his movement from a harmless joke towards an increasingly legitimate threat.

Indeed, it may be that Beaumont was aware of the tension he would be causing with Rafe's increasingly serious roles, as the play's conclusion clearly attempts to assuage audience fears and return them to the "normal" world outside the play. The last time we see the upstart grocer's apprentice is when he comes onstage as his own ghost with a forked arrow through his head, reflecting upon his time "when [he] was mortal" (v. 290). In his final speech, Rafe attempts to weave the disparate parts he has played throughout the play into a coherent narrative that ends in his comic death. Not only does Rafe die in humourous fashion - his warning against "forked heads" (v.332) refers both to arrows and to cuckoldry-he also presents his adventures as May Lord and captain of the militia as a continuation of his adventures as the knight. By having Rafe tie up the loose ends of his own narrative, assure his audience that his many parts were all in jest, and then die in comic fashion, Beaumont attempts to re-establish the social and political equilibrium that was disturbed in the play's opening act, and dispel any anxieties caused by the way that Rafe's role in the play has challenged both the sequential logic of traditional drama and the ideological assumptions of its audience..$^{\circ}$

Keeping in mind that the play opened in the same year as the Midlands Revolt, then, and the fact that as an actor, Rafe has been positioned among those in the know, and that his character has been connected to a famous English rebel through his allusion to Hotspur, consider what Beaumont is staging at the play's conclusion: in the anxious atmosphere of a recently reinstated holiday infamous for its connections to lower-class riots, a lowly apprentice rises to become the leader of the city, and immediately uses this newfound status to call the disgruntled populous to arms against their city's elite. By the time that Rafe closes the vignette by yelling at his small army of pewterers, poulterers, and grocers to "remember, then, whose cause you have in hand" (v.154-155), calling on them to "show to the world you can as well brandish a sword as shake an apron" (v.157-158), it is hardly a surprise that Beaumont's audience was not amused.

\section{The Serious Business of Humour}

Up to this point, I have proceeded by looking for reasons to take Rafe's role in The Knight of the Burning Pestle seriously, but it is this very desire for "seriousness" that may be the primary stumbling block for the play's critics. If Beaumont's play has rarely been mined for its political implications, it is not solely due to his bio- 
graphical details or a repeated oversight of the play's historical contexts. It surely has something do with a critical predisposition against the idea that a burlesque comedy could be capable of carrying serious politics, for, as Jeremy Lopez writes, "the criterion of seriousness" has been the "perennial sticking point for Beaumont and Fletcher criticism." ${ }^{11}$ When Zitner acknowledges that the play includes a good measure of social commentary, for example, he cannot help but wonder if the genre somehow negates its politics: "The behaviour of Venturewell and the reactions of the Citizens and Mistress Merrythought to 'The London Merchant' suggest a critique," he writes, only to add, "but how seriously can we take it?"52 Similarly, Leggatt, even though his essay makes a strong case for the play's anti-aristocratic implications, feels compelled to admit that "it may seem over-solemn to suggest that Beaumont also has a point to make."s3

Our unwillingness to consider the political message of satirical or burlesque comedies like The Knight tells us more about the aesthetic assumptions of our age than it does about Renaissance plays. In his seminal Rabelais and His World (1965), Bakhtin traces the process by which comedy has been relegated to secondary status in theatre directly to the age of Beaumont's play. Bakhtin argues that in contrast to our own understanding of comedy as somehow inherently frivolous, "the Renaissance conception of laughter can be roughly described as follows: Laughter has a deep philosophical meaning ... the world is seen anew, no less (and perhaps more) profoundly than when seen from the serious standpoint." 54 The language with which critics have dismissed Rafe and the politics of Beaumont's play- "how seriously can we take it?" and so on-betrays precisely such an anachronistic underestimation of political efficacy of laughter and the carnivalesque.

Bakhtin goes on to argue that folk festivities and carnival days functioned as a type of "second life" for the people, offering "a completely different, nonofficial, extraecclesiastical and extra political aspect of the world." Importantly, he understands this second life not as an instrumentalized disrespect for a particular authority, but rather as a "temporary suspension of all hierarchic distinctions and barriers among men" that challenges the very idea of a static and stable world order. Although the carnivals may ostensibly be "extra-political" in that they mocked "low" and "high" culture alike, inasmuch as they created "a boundless world of humorous forms and manifestations [that] opposed the official and serious" worlds surrounding them, 55 they constituted a serious threat to those who benefited most from a stable and unquestioned social structure. The carnivalesque, then, should not to be mistaken as simply the humorous, or the comedic, for one can easily imagine a comedy that affirms, rather than challenges, the principle of an official 
and unchanging order. In the same way, positioning Rafe as the Lord of May Day is not simply a comedic gesture; Beaumont invokes the long-standing tradition of the carnival, along with its attendant history of social unrest. It would be going too far to call The Knight an unproblematic example of Bakhtin's carnivalesque, however, for Bakhtin insists that carnival laughter is "universal in scope," "directed at all and everyone, including the carnival's participants." As we have seen, Beaumont mocks nearly everyone in London society and so might seem to be demonstrating the "universal scope" of the carnivalesque, and yet by privileging the positions of actors and playwrights, he retains a segment outside of the carnival, a move that Bakhtin identifies as typical of the "satirist, whose laughter is negative [and who thereby] places himself above the object of his mockery." ${ }^{66}$ Although properly a satire, then, Beaumont clearly draws on the spirit of the carnivalesque to animate Rafe's position of power within the play.

I would like to return briefly to the Midland Revolts that had occurred earlier in 1607 , to demonstrate how the carnivalesque combines the "humourous forms" of carnival with serious political threat. Not only was the Midland Revolt of 1607 unleashed during May Day celebrations, but the rioting intensified to its highest point on May 31, Trinity Sunday, when the "day of religious festival served to catalyze mass mobilisation of both peasants and their allies." 57 Gordon McMullan's account of the event illustrates the relationship between carnival and political transgression: “The country authorities ordered that Leicester's gates be closed, but a substantial number of people left town that night, ostensibly to prepare for Trinity Sunday festivities the next day," he writes. "In fact, they traveled to key loci for enclosure protest." At times, the carnival origins of these riots carried over into their protests. McMullan notes that as the riots spread from village to village, "each riot itself seems to have been something of a ritual, as rioters processed through villages, with a popular leader on horseback at their head, to the tune of pipe and tabor. The marchers were accompanied in the general air of festivity." ${ }^{8} 8$ Moreover, by the time the Midlands Revolt reached its apex, its leader was such a bizarre personality that Rafe looks utterly solemn by comparison. The charismatic John Reynolds, better known as "Captain Pouch," assumed the leadership of the rebellions by assuring the rioters that the magical contents of his leather pouch would protect them from any harm. Not surprisingly, the pouch failed them. Before he was drawn and quartered, authorities emptied the pouch of its only contents: a piece of green cheese. ${ }^{59}$ For Bakhtin, as we have seen, the challenge of the carnivalesque is in its advocacy of a disorder, unreasonableness, and the absurd; if Captain Pouch led the most recent peasant rebellion (which began and escalated on festival days), there would have 
been little reason to think Rafe, especially in his role as Lord of May Day, incapable of leading the next.

\section{Metatheatre and Other Threats}

As part of a larger contextualization of Beaumont's play, it is important to keep in mind the debates that were raging in Jacobean England regarding the power of the theatre, particularly in light of what is now celebrated as the play's startlingly original self-reflexivity. The concerns regarding the morality of "playing parts" that would eventually close the theatres in $\mathbf{1 6 4 2}$ were already circulating in London at the turn of the century, and The Knight plays directly into fears that theatrical presentations of immorality or unrest would corrupt theatregoers. In Carnival and Theatre, Michael Bristol notes that "puritans and other moralists" were especially concerned "with the power of dramatic images to influence the social conduct of the members of the audience." 60 Anti-theatre tracts warned that the theatres were presenting a distorted, even evil, view of both the moral and political worlds. In 1577, for example, John Northbrooke denounced theatres on the grounds that "Satan hath not a more speedie way and fitter schoole to work and teach his desire ... than those places and playes, and theaters" ${ }^{11}$; in the widely read Anatomie of Abuses (1583), Philip Stubbes agrees that "plays were first invented by the Devil," and shows himself to be entering an on-going debate by countering the imagined arguments of a theatre advocate:

Whereas, you say, there are good examples to be learned in them: truly so there are; if you will learn falsehood; if you will learn cozenage; if you will learn to deceive; if you will learn to play the hypocrite, to cog, to lie and falsify ... if you will learn to contemn God and all His laws, to care neither for Heaven nor Hell, and to commit all kind of sin and mischief, you need to go to no other school, for all these good examples may you see painted before your eyes in interludes and plays. ${ }^{62}$

If Northbrooke and Stubbes are admittedly extremes, the Lord Mayor's letter to the Privy Council in 1597 argued on similar grounds, reasoning that plays "move [the audience] wholly into imitation and not to the avoiding of those faults and vices which they represent." 63 The city's response to the letter demonstrates how dangerous theatrical representations were considered to be in the time of Beaumont's play: it resulted in the closure of all of London's theatres, and the declaration, in the Queen's name, that every theatre in London be destroyed. ${ }^{64}$

The theatre was dangerous not simply because it offered entertaining examples of immoral lifestyles, however, and Beaumont's play does more than simply play 
off fears that audience members might begin to imitate the players' characters. It seems the stakes were higher than this, for, as Alan Shepard reminds us, play-acting was "a vice condemned as undercutting the foundations of representational truth on which society itself is built." 65 Critics warned that as acting itself was a form of "dissembling," or lying, the theatre was not only teaching people how to disguise their true nature, but was actually destablizing the entire social order. In 1615, for example, John Stephens described the "common player" by writing that "the statute has done wisely to acknowledge him a rogue errant; for his chief essence is A daily counterfeit ... he is but a shifting companion; for he lives effectually by putting on and off." 66 Similarly, in 1580 Munday asked, "Are [actors] not as variable in heart as they are in their parts?"67 Perhaps it is Stubbes, however, whose work shows most clearly what is at stake. After warning that the theatre is a particularly dangerous form of entertainment - "such is our grooss and dull nature, that what thing we see opposite before our eyes, do pierce further, and print deeper into our hearts and minds, than that thing, which is heard only with the ears" - he insists that actors cannot be separated from the parts they play. "Who will call him a wise man that playeth the part of a fool and a vice?" he asks. "Who can call him a Christian who playeth the part of the Devil?" More than simply worrying about their eternal soul, Stubbes adds that the theatre makes it "verie hard to knowe, who is noble, who is worshipfull, who is a gentleman, [and] who is not." 68 The fear expressed by Beaumont's contemporaries is not just that the theatre might move audiences to mimic bad behaviour, but that acting itself somehow destabilizes the fixed, unchanging identity upon which the social hierarchy is built. As Jean Howard writes, "these treaties pay homage to a static conception of the social order and an essentialist view of human identity as God-given rather than as forged through participation in social processes." 69 This is why it is significant that The Knight shows audience members actually becoming players, and actors becoming audience members, for it literalizes the fears that the theatre exposes all men as actors. If nobility can be reduced to a part one plays, and not something into which one is born, what is there to check social ambition?

At a time when the boundaries regarding what distinguished "acting" from "lying" remained unclear, Beaumont also does his best to blur the lines that distinguish the world of the theatre and the theatre of the world. In fact, there are ways in which the Blackfriars theatre itself was particularly well suited as the setting for Beaumont's blurring of the lines between the "real" and theatrical. According to Stern, for example, the Blackfriars "will have itself been both unrealistic and 'romantic'," given its close and closed quarters, and the "smoke, perfume, and the fixed night that comes with candlelight," tobacco, and fireworks..$^{\circ}$ Moreover, in contrast to the 
Globe, where the wealthiest audience members sat in the "Lord's Room" or in the upper gallery, always well away from the stage, seats at the Blackfriars increased in price as they came closer to the stage - to the point that, for the right price, one could purchase seats on the stage itself. ${ }^{71}$ Stern argues that seeing a play at the Blackfriars "demanded showy wealth," and thus drew "a clientele either with money or concerned to seem to have it." With an audience as conscious of its clothes and presentation as the players were, Beaumont's play simply draws attention to the narrowness of the line between players and audience. Moreover, Stern notes that Blackfriars' plays often included internal events, such as plays-within-a-play, that made props of the on-stage audience members, in such a way that "the play world thus extends out into the whole building." ${ }^{2}$ With its duelling plays and unrelenting erasure of the line between audience and actors, The Knight constitutes an example par excellence of the extension of the world of the play.

The play's interrogation and exploitation of the age's anxieties about the power of theatre begins in its opening scene. As is customary in early modern drama, The Knight of the Burning Pestle opens with a Prologue begging the attention and favour of the audience for the play that is about to be presented. The prologue of a play was traditionally a thoroughly pragmatic moment, meant to give the audience time to settle down, and used to facilitate a pacifying transition between the physical, "real" world of the London theatre, and the imaginative setting represented on the stage. Rather than using the prologue to ease his audience into the world of the play, however, Beaumont calls attention to the artificiality of the moment by having George clamber onto the stage from the audience, interrupt the Prologue, and demand a new play. Since audience members actually interrupting plays was anything but unprecedented, there would have been, however fleeting, a moment of true confusion, in which the audience would have been unclear as to whether George was an actor or an unruly citizen, and whether or not the disruption was scripted. ${ }^{73}$ In that momentary uncertainty, then, every spectator suddenly becomes a potential character in the play; no longer coolly detached observers of The London Merchant, the theatregoers find themselves cast in the role of The Knight of the Burning Pestle's dramatized audience. While the Blackfriars' audience may have been happy to flirt with the idea of becoming a part of the action, there is no indication that they would have been ready for a wholesale erasure of the line between themselves and the world of the play, especially when that world is as uncertain and ambiguous as The Knight's. Positioning both the audience members and his stranded prologue as characters in the play, Beaumont carefully constructs, then maintains this meta- 
theatrical uncertainty, extending this "in between" moment to locate the action of the play within its tension.

The denial of the distinction between actor and audience complements the play's larger carnivalesque challenge to a stable and coherent social structure; as Bakhtin writes, "carnival does not know footlights, in the sense that it does not acknowledge any distinction between actors and spectators." 74 Like the carnivalesque, then, the power of the play's metatheatrical elements resides less in its ability to confront any particular authority figure than in its ability to destabilize the structure in which that authority operates. As Bristol points out, theatre's perceived threat to the social order is directly related to the carnival in that both were feared for their licensed transgression of the social norms. "Theatre and popular festivity were closely related forms of social life," he comments, describing drama and carnival as "neighboring institutions with similar patterns of representation and similar orientations to political and economic practice."75 If the fears surrounding the fluidity of identity were already present in theatres, the play's dissolution of the line between the stage and city-along with its related carnivalesque overturning of the social order and its thinly-veiled references to past revolts and rebellions - would have been anxietyinducing, indeed. Shakespeare may have written "all the world's a stage" several years earlier, but it is Beaumont who shows us what is at stake in the phrase.

\section{Conclusion}

I feel it necessary to close by making it clear that I do not mean to argue that Beaumont's intention with The Knight of the Burning Pestle was to write a political manifesto, to instigate another peasant revolt, or even level a particularly pointed critique at any particular segment of London society. Rather, I want to point out that the play was written with an aim to conjure up the most pressing political anxieties of the age, to explore them, exploit them, and, yes, to laugh at them. Distracted by Beaumont's biography and overlooking the political efficacy of Renaissance comedy, critics have repeatedly underestimated the play's engagement with its age's deep anxieties surrounding festival days, the related threat of the theatrical mimesis, and its polemic allusions to recent political upheaval. The issues being examined and troubled by the play - human nature, mimesis, and security — were so foundational to the politics and metaphysics of the age that Beaumont produced a piece of art that may have simply overwhelmed many of its viewers.

Finally, I have tried to show that many of these anxieties come to a head in Beaumont's hero, Rafe, who, for too long, has been unjustly passed over as the fool 
whose part he is forced to play. Indeed, the play's concluding lines may even suggest that the interpretation of the play ought to hang on one's reading of Rafe: after The London Merchant has ended and all its actors have left the stage, George asks Nell to leave, explaining to her that "the play's done" (epilogue 1), but Nell remains on stage for a final speech. Nell turns to the audience members who were seated on the stage and says: "I thank you all, gentlemen, for your patience and countenance to Rafe, a poor fatherless child ... I do hope you like the youth, but I would be glad to know the truth. I refer it to your own discretions whether you will applaud him or no" (Epilogue 3-9). The question we are left with at the end of the play, then, is how we are to understand Rafe's role in the play. Even if we are not prepared to lift him up as a genuine revolutionary, Rafe must be recognized as a much more weighty character than critics have traditionally considered him to be-for the script allows for a performance of The Knight in which Rafe is played "straight," as the smartest character on the stage with a true passion for drama and a serious grudge against the social structures under which he must serve. ${ }^{76}$

\section{Notes}

1. Francis Beaumont, The Knight of the Burning Pestle (1607), ed. Sheldon P. Zitner (Manchester: Manchester University Press, 1984), pp. 51-162, act 5, 11. 157-58. All subsequent references to this play will occur in the main text, in parentheses.

2. Of the Midlands Revolts, Whitney Jones writes that "John Martin envisages the outbreak as 'the last peasant revolt in England,' and Roger Manning concurs that something more than 'a series of enclosure riots' was involved," in The Tree of Commonwealth, 1450-1793 (London: Associated University Presses, 2000), p. 133. My description of the revolt is drawn primarily from the following works: Roger B. Manning, Village Revolts: Social Protest and Popular Disturbances in England, 1509-1640 (Oxford: Clarendon Press, 1988); Gordon McMullan, The Politics of Unease in the Plays of John Fletcher (Amherst: The University of Massachusetts Press, 1994); and John E. Martin, Feudalism to Capitalism: Peasant and Landlord in English Agrarian Development (New Jersey: Humanities Press, 1983).

3. Although there have been debates over the precise date of The Knight, Zitner and Finklepearl each suggest that a critical consensus of 1607 has now been reached. See Sheldon P. Zitner, "Introduction,” Francis Beaumont: The Knight of the Burning Pestle (Manchester: Manchester University Press, 1984), pp. 1-49, 10; and Philip J. Finkelpearl, Court and Country Politics in the Plays of Beaumont and Fletcher (New Jersey: Princeton University Press, 1990), p. 81. That the play was "rushed out" can be seen from Walter Burre's dedicatory epistle attached to its first printing, which states the play was "in eight days ... was begot and born [and] soon after ... exposed to the wide world.” 
4. Finklepearl, p. 83

5. William W. Appleton writes that "Hazelton Spencer has suggested that the critical satire was resented by the citizenry. Alfred Harbage denies this by pointing out that the citizens were not in the audience, and that the exceptional moderation of the satire probably accounted for its failure," in Beaumont and Fletcher: A Critical Study (London: George Allen \& Unwin Ltd., 1956), p. 14; both Finklepearl and Beaumont himself argue it was simply too original for the audience to handle (see Finklepearl, p. 82).

6. Lee Bliss, Francis Beaumont (Boston: Twayne Publishers, 1987), preface.

7. Appleton, preface.

8. See Finklepearl, esp. chapters 1-3; and Sandra Clark, The Plays of Beaumont and Fletcher: Sexual Themes and Dramatic Representation (Toronto: Harvester Wheatsheaf, 1994), pp. 1-23.

9. Quoted in Clark, p. 3

10. John F. Danby, Elizabethan and Jacobean Poets: Studies in Sidney, Shakespeare, Beaumont \& Fletcher (London: Faber and Faber, 1952), p. 157.

11. Margot Heinemann, Puritanism and Theatre: Thomas Middleton and opposition drama under the early Stuarts (Cambridge: Cambridge University Press, 1980), p. 38.

12. Dana Aspinall, "The Role of Folk Humor in Seventeenth-Century Receptions of Beaumont's The Knight of the Burning Pestle," Philological Quarterly (Spring 1997), pp. 169-91, 170, 171.

13. Finklepearl, p. 13.

14. Bliss, Francis, p. 8.

15. Finklepearl, p. 7. Finklepearl's reading of Beaumont's views may be supported by the fact that two of Beaumont and Fletcher's later plays faced censorship for their politics-The Maid's Tragedy for its representation of regicide, and Philaster for its slightly too-obvious allegorical representation of the Stuart relationship with the Spanish Hapsburgs. See Janet Clare, "Art made tongue-tied by authority": Elizabethan and Jacobean Dramatic Censorship (New York: Manchester University Press, 1990), pp. $165-67 ; 184-87$.

16. Alexander Leggatt, "The Audience as Patron: The Knight of the Burning Pestle," in Shakespeare and Theatrical Patronage in Early Modern England, ed. Paul Witfield White and Suzanne R. Westfall (London: Cambridge University Press, 2002), pp. 295-315, 297.

17. Bliss, Francis, p. 8.

18. Leggatt, "Audience," p. 297.

19. Bliss, Francis, p. 8.

20. Finklepearl, p. 6.

21. Colin Counsell, "Introduction," The Knight of the Burning Pestle (London: Nick Hern Books, 2001), p.x.

22. John Doebler, "Introduction," Francis Beaumont: The Knight of the Burning Pestle (Lincoln: University of Nebraska Press, 1967), xi-xxiv, xix. 
23. Stanley Wells, “Shakespearian Burlesques," Shakespeare Quarterly 16.1 (Winter, 1965), pp. 49-61, 49.

24. Doebler, p. 11.

25. Lee Bliss, "Pastiche, burlesque, tragicomedy," The Cambridge Companion to English Renaissance Drama, ed. A. R. Braunmuller and Michael Hattaway (New York: Cambridge University Press, 1990), pp. 237-62, 242-43.

26. Zitner, p. 57 .

27. Doebler, p. 11.

28. William Shakespeare, I Henry IV (1598), in The Norton Shakespeare, ed. Stephen Greenblatt, et al. (New York: W. W. Norton \& Company, 1997), pp. 1157-1224.

29. Stephen Greenblatt ed., The Norton Shakespeare (New York: W. W. Norton \& Company, 1997), p. 1147.

30. Doebler, p. 22.

31. Lee Bliss, "'Plot mee no plots': The Life of Drama and the Drama of Life in The Knight of the Burning Pestle," Modern Language Quarterly 45 (1984), pp. 3-21, 13.

32. Bliss, "Plot," p. 13.

33. Bliss, "Plot," p. 13

34. Although I am jumping from Rafe's earliest appearances to his transformation at the play's end, it is important to note that several critics have found evidence to suggest that Beaumont intended the body of the play to contain a social critique. Finklepearl, for example, argues "the players' play exposes the banality of bourgeois pieties" (p. 88). Lucy Munro argues that when the citizens demand a match between Rafe and the Princess of Cracovia, Beaumont draws attention to the play's "ideological implications" by having a player complain that "it will show ill-favouredly to have a grocer's prentice to court a king's daughter." See Munro's “The Knight of the Burning Pestle and Generic Experimentation," in Early Modern Drama: A Critical Companion, ed. Garrett A. Sullivan, et al. (Oxford: Oxford University Press, 2006), pp. 189-99, 195. Finally, even Rafe's mockery of knighthood is a challenge to the established social order, if, as Linda Colley writes, "by definition, chivalry ... reaffirms the paramount importance of custom, hierarchy and inherited rank," in Britons: Forging the Nation, 1707-1837 (2nd ed., New Haven: Yale University Press, 2005), p. 148.

35. Zitner, p. 41.

36. Munro, p. 193.

37. Tiffany Stern, "Taking Part: Actors and Audience on the Stage at Blackfriars," Inside Shakespeare: Essays on the Blackfriars Stage, ed. Paul Menzer (Selinsgrove: Susquehanna University Press, 2006), pp. 35-53, 47.

38. Bliss, "Plot," p. 14.

39. Mikhail Bakhtin, Rabelais and His World, trans. Hélene Iswolsky (1965; Bloomington: Indiana University Press, 1984), p. 262.

40. See McMullan, p. 42; Martin, p. 164; Janette Dillon, "Is not all the world Mile End, mother?': The Blackfriars Theater, the City of London, and The Knight of the Burning Pestle," in Medieval and Renaissance Drama in England 9 (1997), pp. 127-48, 133. 
41. Martin, p. 168.

42. Lord Mayor of London, "Letter to the Privy Council," in Shakespeare's Theatre: A Sourcebook, ed. Tanya Pollard (Oxford: Blackwell Publishing, 2004), p. 332.

43. Manning, pp. 192, 198.

44. Zitner (p. 146) even sees a gesture towards the Gunpowder Plot of 1605 when Rafe ends his May Day speech by declaring, "God save our king, and send his country peace, And root out treason from the land” (Int. IV 59-64).

45. Zitner, p. 144 .

46. R.B. Dobson, Peasants' Revolt of 1381 (2nd ed., London: Macmillan Press Ltd., 1983), p. 354. If reading the reference of Mile End as gesture towards a revolt that took place 225 years earlier seems a stretch, there is reason to believe the "Great Revolt" would have been fresh in the minds of Beaumont's audience. Dobson's claim that "new plays on the theme of the Peasants' Revolt have always tended to appear on the London stage at times of political turmoil and social conflict" (p. xxii) is borne out by the fact that The Life and Death of Jack Straw, an anonymous play dramatizing the leader of the 1381 Peasants' Revolt, had begun playing in 1592 (see Maya Mathur, "An Attack of the Clowns: Comedy, Vagrancy, and the Elizabethan History Play," Journal for the Early Modern Cultural Studies 7.1 [2007], pp. 33-54, 36) and proved popular enough to be published as a text in 1606 , the year before The Knight was produced. Whether or not Beaumont was directly referencing the Great Revolt, then, it would likely have been in minds of his audience and, along with the invocation of the much more recent Midlands Revolts, would have served to tie the young grocer to England's history of peasant uprisings.

47. Dillon, p. 141.

48. Martin, p. 143 .

49. Martin, p. 143 .

50. However, if it seems that Rafe's death is an accidentwith an arrow as he wanders into Moorfields, which, according to Zitner, was near an area used for archery (p. 161) - it is worth noting that Rafe also claims he was almost killed in his shop earlier that day (V. 319-22). Is it possible his death is more than a mere accident?

51. Jeremy Lopez, Theatrical Convention and Audience Response in Early Modern Drama (Cambridge: Cambridge University Press, 2003), p. 171.

52. Zitner, p. 18.

53. Leggatt, "Audience," p. 311.

54. Bakhtin, p. 66.

55. Bakhtin, pp. 5-6, 15, 4 .

56. Bakhtin, pp. 11-12.

57. Martin, p. 166.

58. McMullan, pp. 41-42.

59. Manning, p. 233. 
60. Michael D. Bristol, Carnival and Theatre: Plebeian Culture and the Structure of Authority in Renaissance England (New York and London: Methuen, 1985), p. 108.

61. John Northbrooke, "A Treatise Against Dicing, Dancing, Plays, and Interludes, with Other Idle Pastimes” (1577), in Shakespeare's Theatre: A Sourcebook, ed. Tanya Pollard Oxford: Blackwell Publishing, 2004), pp. 2-18, 2-3.

62. Philip Stubbes, "Anatomy of Abuses" (1583), in Shakespeare's Theatre: A Sourcebook, pp. 117-123, 121-122.

63. Lord Mayor of London, p. 321.

64. It would take more than 40 years before the theatres were closed on ideological grounds, however. For a discussion on the possible readings of the Order, see Glynne Wickham's “The Privy Council Order of 1597 for the Destruction of all London's Theatres" in The Elizabethan Stage, ed. David Galloway (Oshawa: Alger Press Ltd., 1969), pp. 21-44.

65. Alan Shepard, Marlowe's Soldiers: Rhetorics of Masculinity in the Age of the Armada (Burlington: Ashgate Publishing Co., 2002), p. 4.

66. John Stephens, from Satyricall Essayes, Characters and Others (1615; 2nd ed), in Elizabethan-Jacobean Drama, ed. G. Blakemore Evans (London: A\&C Black, 1988), pp. 95-96.

67. Anthony Munday, from A Second and Third Blast of Retrait from Plaies and Theaters (1580), in Elizabethan-Jacobean Drama, pp. 94-95.

68. Stubbes, pp. 117, 122, ciiv.

69. Jean E. Howard, The Stage and Social Struggle in Early Modern England (New York: Routledge, 1994), p. 43.

70. Stern, p. 46.

71. Charles Wallace suggests "the fad of sitting on the stage came into vogue with the Blackfriars in 1597"; but Gerald Bentley counters that Wallace "was certainly wrong in thinking that the custom was initially or exclusively at Blackfriars." See Charles William Wallace, The Children of the Chapel at Blackfriars 1597-1603 (New York: AMS Press, 1908), p. 130; Gerald Eades Bentley, The Jacobean and Caroline Stages, Vol. vi: Theatres (Oxford: Clarendon Press, 1968), p. 7). Whether or not the Blackfriars was the first theatre to sell seats on the stage may be disputed, but it is clear that one went to the Blackfriars not only to see, but to be seen.

72. Stern, pp. $43,47$.

73. Although it is true that Beaumont was not the first to have a prologue interrupted as a part of the play, The Knight far exceeds its precedents in both the scale and duration of its metatheatrical elements. As Finklepearl writes, "much Renaissance drama calls attention to its artificiality, but ... none anatomizes more remorselessly than the Knight of the Burning Pestle the flimsy materials out of which the dramatic experience is built" (p. 95).

74. Bakhtin, p. 7 .

75. Bristol, p. 4 . 
76. I am grateful to Alan Shepard, Paul Mulholland, and Adrian Del Monte, as well as to the two anonymous readers, for their suggestions and insights on earlier drafts of this essay. I also want to gratefully acknowledge the Social Sciences and Humanities Research Council of Canada for the financial support that made this paper possible. 